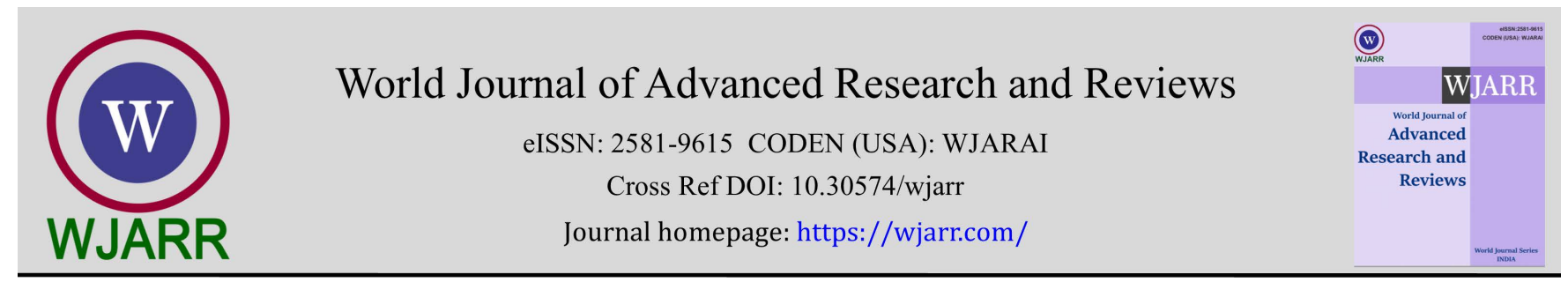

(REVIEW ARTICLE)

\title{
Management of E-waste in India - Challenges and recommendations
}

\author{
Priya Jeyaraj * \\ 33 CDU, 33 Corp, Indian Armed Forces, India.
}

World Journal of Advanced Research and Reviews, 2021, 11(02), 193-218

Publication history: Received on 15 July 2021; revised on 13 August 2021; accepted on 15 August 2021

Article DOI: https://doi.org/10.30574/wjarr.2021.11.2.0329

\begin{abstract}
E-waste management is an extremely important contemporary current affairs topic in the world and in India. This study presents an in-depth and well researched qualitative analysis of E-waste management and the challenges faced. The study comprehensively puts forth the problem statement, threat, existing norms and parameters, legislations dealing with E-waste management, and more importantly, their lacunae in their implementation. The Study also offers recommendations for its betterment, which are implementable.
\end{abstract}

Keywords: Waste; Hazards; Electronic and Electrical equipment (EEE); E-waste management; Recommendations; Recycling

\section{Introduction}

The world has historically documented a massive augmentation of human resources due to the industrial revolution. It contributed to immense progress in terms of exploration, transport, trade and economy as a whole. It established a new world order. However, with the advent of a newer energy source called electricity the dynamics of the industrial world started changing, resulting in the application on the electrical and electronic field, which far surpassed the industrial revolution [1]. Furthermore, the invention of the computer opened up yet another limitless dimension. Electronics, per say, have led to enhanced connectivity, productivity, reduced distances. The e-industry is so dynamic that products churned out by it become obsolete, redundant and outdated at a rate that is alarming. This is compounded by the fact that production costs are decreasing and consumer buying power is ever increasing [2]. At a consumer level frequent recycling of e products has become a norm, with little or no concern on the disposal of the discarded item.

Over the past century, the world seems to have gradually but surely woken up to the threat of accumulating waste. The Basel convention of 1992 states that wastes are substances or objects, which are disposed of or intended to be disposed of, or required to be disposed of by national laws. This implies that nations individually must recognize and acknowledge the problem at hand and address it on priority [3-5]. The Govt of India has put this responsibility on the Central Pollution Control Board (Ministry of Environment and Forests), which is the statutory body to frame laws on waste disposal of various kinds in our country. There are various kinds of wastes for which laws are framed, as their accumulation and improper disposal can independently be a threat to humanity and environment as a whole. municipal, industrial, agriculture, bio-medical, radioactive and E-waste.

Since the past two decades the world has stood up and recognized the independent threat of e-waste. Earlier it was being disposed of with common municipal waste. Not only is e-waste an unrestrained source of energy consumption, but also has become a steady supplier of waste material [3]. The alarming rate of growth of e -products and equally high rate of products becoming obsolete/outdated, has made e-waste the fasted growing waste stream in the world. The spectrum of items in e-waste comprises of the whole gamut of electrical and electronic items, such as refrigerators,

\footnotetext{
* Corresponding author: Priya Jeyaraj

33 CDU, 33 Corp, Indian Armed Forces, India.
}

Copyright (C) 2021 Author(s) retain the copyright of this article. This article is published under the terms of the Creative Commons Attribution Liscense 4.0. 
washing machines, computers and their peripherals, TV, mobiles, iPods etc [6-8]. Majority of them contain toxic materials posing a serious challenge to environment and human health. The European Union (EU) has defined the stream as 'Waste Electrical and Electronic Equipment (WEEE), further dividing it into components, components, subassemblies and consumables. In India, it is simply termed as e-waste, which broadly includes loosely discarded, surplus, obsolete, broken electrical and electronic devices [9-10]. The United Nations University ADDRESS project documents that e-waste volume placed on the market since 1990 has grown from 19.5 million tonnes to to approximately 75 million tonnes by 2015 [11-15].

\section{Aim}

The aim of this study was to examine the present system of management of e-waste in India along with the challenges faced and offer recommendations for its betterment.

\section{Objectives}

Objectives of this Study were: -

- To study in depth the present problem of e-waste across the world, and in India.

- To study principles of management, regulations and legislation in India regarding e-waste.

- To study challenges faced in management of e-waste.

- To offer recommendations to effectively manage e-waste.

\section{Methodology}

A qualitative assessment and research were conducted, incorporating the following: -

- In-depth study of available literature in libraries and on web.

- Analysis of situation and challenges in respect of legislations existing on ground.

- Implementable recommendations to improve management of E-waste.

\subsection{Scope of the Study}

The study has been divided into various sub-components to have a better understanding of the subject. Various participants have addressed the sub-components separately as under: -

- What is E-waste?

- Situation and Threat of e-waste in the World

- $\quad$ Situation of E-waste in India

- Environmental and Health Hazards of E-waste

- Recycling of E-waste and Stakeholders

- Principles of E-waste Management

- Lacunae in E-waste Management in India

- Legislation

- Challenges \& Recommendations

\section{Introduction}

The definition of e-waste is essential before an estimation of its volume and impact on environment. There is global inconsistency in the understanding and application of the term "e-waste" in both legislation and everyday use. This has resulted in many definitions contained within e-waste regulations, policies and guidelines. E-waste in simple terms contains hazardous substances that, if treated inappropriately at end-of-life, can damage human health and the environment. It also contains complex valuable materials, such as precious metals, which need to be treated properly to effectively recover them with minimal environmental impact.

\section{Clarity on Electrical and Electronic Equipment (EEE)}

To provide a foundation to support the definition of e-waste, it is necessary to first define EEE. The definition of EEE is: "Any household or business item with circuitry or electrical components with power or battery supply." This definition 
of EEE is independent to the definition used to determine the product scope of any e-waste or producer responsibility legislation.

The Step definition of EEE includes both household and business items. Some e-waste legislation differentiates the two as being separate streams and impose differing obligations on producers of household and business products. It is important to note that falling within the accepted definition of EEE is not the same as falling within the scope of a particular national or local e-waste policy. Within specific e-waste legislation, the scope includes or excludes certain types of EEE [16]. The European Union's Waste Electrical and Electronic Equipment (WEEE) Directive, 2012/19/EU, classifies all electrical and electronic items as potentially being in scope, with some specific exceptions such as filament bulbs and large-scale fixed installations $[17,18]$. In the United States, there is no federal e-waste law; therefore, there is no nationwide legal definition of e-waste scope. There are, however, state laws where the inclusion or exclusion of products varies from state to state. In general, references to "e-waste" in the United States refer to mobile phones, Information Technology(T) equipment and televisions, while other electrical and electronic appliances are mostly regulated as municipal solid [19-21].

\section{Definition of E-waste}

The term "e-waste" itself is self-explanatory, in the sense that it is an abbreviation of "electronic waste". A key part of the definition is the word "waste" and what it logically implies - that the item has no further use and is rejected as useless or excess to the owner in its current condition. The definition of e-waste that has been agreed: - "E-Waste is a term used to cover items of all types of electrical and electronic equipment (EEE) and its parts that have been discarded by the owner as waste without the intention of re-use." It is important to note that the definition includes all types of EEE, as there is no room for regional variance or preference in a global definition; the fact that the item in question meets the definition "with circuitry or electrical components with power or battery supply" qualifies it for inclusion [22]. The inclusion of "parts" within the definition refers to parts that have been removed from EEE by disassembly and are electrical or electronic in nature. The use of the term "discarded" is also central to this definition, meaning to throw away or get rid of as useless. The term implies that the owner considers the item in question excess or waste [23, 24]. It is the critical point at which the potential nature of the item changes from a useful product to that of waste.

\section{Perceptions of E-waste by the Owner}

An area of inconsistency noted by owners or asset controllers of EEE is the point at which the product becomes waste. This is where the decision of the owner defines if the item in question is e-waste, or if it can be directly re-used by someone else for the same purpose for which the product was originally designed. In the latter, the equipment is not considered waste. The act of determining a fully functional product as e-waste by the owner appears to be widespread, which potentially impacts the opportunity for reuse by blurring the suitability of the item for reuse. This area of inconsistency highlights the inappropriate use of the term "discard", as well as the act of discarding. The word "discard" is defined in the Merriam Webster dictionary as "to throw (something) away because it is useless or unwanted", and in the Collins English Dictionary as "to get rid of as useless or undesirable". It is in line with the waste hierarchy (reduce, reuse, recycle) and also environmentally preferable that functional EEE items are not discarded as waste, but rather given an opportunity for reuse either directly by the owner, who may choose to donate or sell the item, or by a specialist organization that may donate or sell the item following a functional test, data wipe, evaluation process or repair [26].

The act of discarding EEE as e-waste occurs when the owner decides the item is no longer useful to them (due to failure, technical capability, cosmetic condition, age, replacement, organizational policy, depreciation, etc.). The owner usually discards the item to be collected for preparation for reuse (a process involving functionality testing, refurbishment, data wipe or repair) or recycling depending on the condition of the item. The EEE does not need to be non-functional for it to be designated as e-waste by the owner, as it is the owner's opinion or choice to discard as e-waste if they so decide. It is the responsibility of the receiving party to determine how best to maximize the value of the item that they have received. The motivation for directly discarding items for recycling rather than for preparation for reuse may be due to lack of functionality, age, cosmetic condition or business policy and would be broken down into component materials for recycling into raw material. However, large amounts of EEE are still disposed of in household bins going directly to disposal, skipping over the possibility for any reuse or recycling [27]. There are situations where an owner (often business) has agreed to return an EEE item to a manufacturer, under a service, leasing or trade-in contract, for example. In these and similar situations, this return is not an act of discarding, and, as such, the item is not considered or treated as e-waste. 
Table 1 Definition of terms

\begin{tabular}{|c|c|}
\hline Manufacture & The phase of the EEE product lifecycle where it is manufactured. \\
\hline Use & The phase of the product lifecycle where it is used for the first time \\
\hline Discard & $\begin{array}{l}\text { The decision by the owner to discard or not discard the product. } \\
\text { Discarding indicates it becomes e-waste, whereas not discarding and } \\
\text { routing to reuse indicates it is not waste. }\end{array}$ \\
\hline Reuse & $\begin{array}{l}\text { "Reuse of electrical and electronic equipment or its components is to } \\
\text { continue the use of it (for the same purpose for which it was conceived) } \\
\text { beyond the point at which its specifications fail to meet the } \\
\text { requirements of the current owner and the owner has ceased use of the } \\
\text { product". Products could be donated or traded before or in this phase. }\end{array}$ \\
\hline $\begin{array}{l}\text { Preparation for } \\
\text { Reuse }\end{array}$ & $\begin{array}{l}\text { Preparation for reuse comprises any operation performed to bring } \\
\text { used EEE or its components into a condition to meet the requirements } \\
\text { of a next potential owner. }\end{array}$ \\
\hline Recycle & $\begin{array}{l}\text { The phase of the product lifecycle where due to lack of functionality, } \\
\text { cosmetic condition or age the product is broken down into component } \\
\text { materials and recycled into raw material for use in the manufacture of } \\
\text { new EEE or other products. }\end{array}$ \\
\hline Disposal & $\begin{array}{l}\text { Material that cannot be recycled into raw material for use in } \\
\text { manufacture of new EEE or other products would need to be disposed } \\
\text { of using other methods, such as energy recovery or landfill. Items that } \\
\text { are disposed of in household bins may move directly to this phase } \\
\text { avoiding any opportunity of reuse or recycling. }\end{array}$ \\
\hline
\end{tabular}

\section{Situation and threat of E-waste in the world}

\subsection{Situation of E-waste Worldwide}

Electronic waste (e-waste) makes up five percent of all municipal solid waste worldwide, nearly the same amount as all plastic packaging, but it is much more hazardous. It's not only developed countries that generate e-waste; Asia discards an estimated 12 million tonnes each year. E-waste is now the fastest growing component of the municipal solid waste stream because people are upgrading their mobile phones, computers, televisions, audio equipment and printers more frequently than ever before. Mobile phones and computers are causing the biggest problem because they are replaced most often. In Europe e-waste is increasing at three to five percent a year, almost three times faster than the total waste stream [28].

Rapid changes in technology, changes in media (tapes, software, MP3), falling prices, and planned obsolescence have resulted in a fast-growing surplus of electronic waste around the globe. Technical solutions are available, but in most cases, a legal framework, a collection, logistics, and other services need to be implemented before a technical solution can be applied. Display units (CRT, LCD, LED monitors) [29, 30], processors (CPU, GPU, or APU chips), memory (DRAM or SRAM), and audio components have different useful lives. Processors are most frequently outdated and are more likely to become "e waste", while display units are most often replaced while working without repair attempts, due to changes in appetites for new display technology.

An estimated 50 million tons of e-waste are produced each year. The USA discards 30 million computers each year and 100 million phones are disposed of in Europe each year. The Environmental Protection Agency estimates that only 15$20 \%$ of e-waste is recycled, the rest of these electronics go directly into landfills and incinerators. In 2006 , the United Nations estimated the amount of worldwide electronic waste discarded each year to be 50 million metric tons. According to a report by UNEP titled, "Recycling - from E-Waste to Resources," the amount of e-waste being produced - including mobile phones and computers - could rise by as much as 500 percent over the next decade in some countries, such as India [31].

The United States is the world leader in producing electronic waste, tossing away about 3 million tons each year. China already produces about 2.3 million tons (2010 estimate) domestically, second only to the United States. Despite having 
banned e-waste imports, China remains a major e-waste dumping ground for developed countries. Society today, revolves around technology and by the constant need for the newest and most high-tech products we are contributing to mass amount of e-waste. Since the invention of the iPhone, cell phones have become the top source of e-waste products because they are not made to last more than two years. As of 2013, Apple has sold over 796 million iDevices (iPod, iPhone, iPad). Cell phone companies make cell phones that are not made to last so that the consumer will purchase new phones. Companies give these products such short life spans because they know that the consumer will want a new product and will buy it if they make it.

In the United States, an estimated $70 \%$ of heavy metals in landfills come from discarded electronics. While there is agreement that the number of discarded electronic devices is increasing, there is considerable disagreement about the relative risk (compared to automobile scrap, for example), and strong disagreement whether curtailing trade in used electronics will improve conditions, or make them worse. According to an article in Motherboard journal, attempts to restrict the trade have driven reputable companies out of the supply chain, with unintended consequences.

\subsection{More E-Waste is Trashed than Recycled}

More e-waste ends up in landfills and incinerators than is being recycled, although recycling numbers continue to rise. The primary data comes from an annual estimate by the Environmental Protection Agency (EPA) whose most recent data (as of summer 2015) is for 2013. This shows that US generated 3,140,000 tons of e-waste, in 2013 and recycled $40 \%$, up from 30\% in 2012.It is unclear whether the large increase in the electronics recycling rate from 2012 to 2013 is due to an actual increase in recycling or the result of improved and expanded data [32]. As per the EPA, in USA currently about $60 \%$ of discarded electronics end up in the trash. While many states are passing laws to prevent e-waste from going into their landfills and incinerators, it's still legal to trash electronics in many states.

\subsection{Global Issues Regarding E-waste Trade}

A proposed theory is that increased regulation of electronic waste and concern over the environmental harm in nature economies creates an economic disincentive to remove residues prior to export. Critics of trade in used electronics maintain that it is still too easy for brokers calling themselves recyclers to export unscreened electronic waste to developing countries, such as China, India and parts of Africa, thus avoiding the expense of removing items like bad cathode ray tubes (the processing of which is expensive and difficult) [33]. The developing countries have become toxic dump yards of e-waste.

Recycling of copper, silver, gold, and other materials from discarded electronic devices is considered better for the environment than mining. They also state that repair and reuse of computers and televisions has become a "lost art" in wealthier nations and that refurbishing has traditionally been a path to development. South Korea, Taiwan, and southern China all excelled in finding "retained value" in used goods, and in some cases have set up billion-dollar industries in refurbishing used ink cartridges, single use cameras, and working Cathode Ray Tubes (CRTs).

Refurbishing has traditionally been a threat to established manufacturing, and simple protectionism explains some criticism of the trade. Works like "The Waste Makers" by Vance Packard explain some of the criticism of exports of working product, for example, the ban on import of tested working Pentium 4 laptops to China, or the bans on export of used surplus working electronics by Japan.

Opponents of surplus electronics exports argue that lower environmental and labour standards, cheap labour, and the relatively high value of recovered raw materials leads to a transfer of pollution generating activities, such as smelting of copper wire. In China, Malaysia, India, Kenya, and various African countries, electronic waste is being sent to these countries for processing, sometimes illegally. Many surplus laptops are routed to developing nations as "dumping grounds for e-waste". Since the United States has not ratified the Basel Convention, 1989 or its Ban Amendment, and has few domestic federal laws forbidding the export of toxic waste [33, 34], the Basel Action Network estimates that about $80 \%$ of the electronic waste directed to recycling in the U.S. does not get recycled there at all, but is put on container ships and sent to countries such as China.

Proponents of the trade say growth of internet access is a stronger correlation to trade than poverty. Haiti is poor and closer to the port of New York than Southeast Asia, but far more electronic waste is exported from New York to Asia than to Haiti. Thousands of men, women, and children are employed in reuse, refurbishing, repair, and remanufacturing, unsustainable industries in decline in developed countries [35]. Denying developing nations access to used electronics may deny them sustainable employment, affordable products, and internet access, or force them to deal with even less scrupulous suppliers. 
Opponents of the trade argue that developing countries utilise methods that are more harmful and more wasteful. An expedient and prevalent method is simply to toss equipment onto an open fire, in order to melt plastics and to burn away non-valuable metals. This releases carcinogens and neurotoxins into the air, contributing to acrid, lingering smog. These noxious fumes include dioxins and furans. Concerns over exports of electronic waste were raised in press reports in India, Ghana, Côte d'Ivoire, and Nigeria. The research undertaken by the Countering WEEE Illegal Trade (CWIT) project, funded by European Commission, found that in Europe, only 35\% (3.3 million tons) of all the e-waste discarded in 2012 , ended up in the officially reported amounts of collection and recycling systems. The other $65 \%$ (6.15 million tons) was either exported (1.5 million tons) [36], recycled under noncompliant conditions in Europe (3.15 million tons), scavenged for valuable parts (750,000 tons) or simply thrown in waste bins (750,000 tons).

\subsection{Guiyu: The E-waste Capital of the World}

Guiyu in the Shantou region of China is a massive e-waste processing community. It is often referred to as the "e-waste capital of the world." Traditionally, Guiyu was an agricultural community; however, in the mid1990s it transformed into an e-waste recycling center involving over $75 \%$ of the local households and an additional 100,000 migrant workers. Thousands of individual workshops employ labourers to snip cables, pry chips from circuit boards, grind plastic computer cases into particles, and dip circuit boards in acid baths to dissolve the precious metals. Others work to strip insulation from all wiring in an attempt to salvage tiny amounts of copper wire. Uncontrolled burning, disassembly, and disposal has led to a number of environmental problems such as groundwater contamination, atmospheric pollution, and water pollution either by immediate discharge or from surface runoff (especially near coastal areas), as well as health problems including occupational safety and health effects among those directly and indirectly involved, due to the methods of processing the waste [37]. A number of studies have been conducted to measure a number of chemicals associated with informal e-waste recycling in the populations.

A study that enrolled children from Guiyu and a control site $50 \mathrm{~km}$ away to measure blood lead levels (BLLs) found thatthe average BLL in Guiyu was $15.3 \mathrm{ug} / \mathrm{dL}$ compared to $9.9 \mathrm{ug} / \mathrm{dL}$ in the control site. In the United States, the CDC has set a reference level for blood lead at $5 \mathrm{ug} / \mathrm{dL}$. High levels of lead in young children can impact IQ and the development of the central nervous system. The highest concentrations of lead were found in the children of parents whose workshop dealt with circuit boards and the lowest was among those who recycled plastic. Six of the many villages in Guiyu specialize in circuit board disassembly, seven in plastics and metals reprocessing, and two in wire and cable disassembly [38].

Greenpeace, an environmental group, sampled dust, soil, river sediment, and ground water in Guiyu. They found very high levels of toxic heavy metals and organic contaminants in both places. Lai Yun, a campaigner for the group found "over 10 poisonous metals, such as lead, mercury, and cadmium." Guiyu is only one example of digital dumps but similar places can be found across the world in Nigeria, Ghana, and India. With amounts of e-waste growing rapidly each year urgent solutions are required.

\subsection{Information Security}

E-waste presents a potential security threat to individuals and exporting countries. Hard drives that are not properly erased before the computer is disposed of can be reopened, exposing sensitive information. Credit card numbers, private financial data, account information, and records of online transactions can be accessed by most willing individuals. Organized criminals in Ghana commonly search the drives for information to use in local scams. Electronic files about government contracts have been discovered on hard drives found in Agbogbloshie, in Accra, Ghana. Multimillion dollar agreements from United States security institutions such as the Defense Intelligence Agency (DIA), the Transportation Security Administration, and Homeland Security have all resurfaced in Agbogbloshie [39].

\section{Situation and threat of E-waste in India}

\subsection{Volume of E-waste Generated}

A study released by the Electronics Industry Association of India (ELCINA) at the electronics industry expo - "Componex Nepcon 2009" had estimated the total e-waste generation in India at a whopping 4.34 lakh tonnes by end 2009.The CPCB has estimated that it will exceed the 8 lakh tonnes or 0.8 MT mark by 2012. India stands fifth in e-waste generation producing around 1.7 lakhs metric tonnes per annum. According to an ASSOCHAM-cKinetics study (2016), India is the fifth largest producer of e-waste in the world. It generates around 18 lakh metric tonnes (MT) e-waste per annum and is likely to generate 52 lakh metric tonnes (MT) per annum by 2020. E-waste in the country is growing at a compound annual growth rate of about $30 \%$ which is a major cause for concern. 
There are ten states that contribute to 70 per cent of the total e-waste generated in the country, while 65 cities generate more than 60 per cent of the total e-waste in India. Among the ten largest e-waste generating states, Maharashtra ranks first followed by Tamil Nadu, Andhra Pradesh, Uttar Pradesh, West Bengal, Delhi, Karnataka, Gujarat, Madhya Pradesh and Punjab. Maharashtra generates 20,270 tons of e-waste per year. 70\% of the total e-waste collected at recycling units was actually dumped by the developed nations. According to a Delhi based study, about 25000 workers are employed at scrap yards in Delhi. Among the top ten cities generating e-waste, Mumbai ranks first followed by Delhi, Bengaluru, Chennai, Kolkata, Ahmedabad, Hyderabad, Pune, Surat and Nagpur.

Table 2 Top Ten Cities of India generating E-waste

\begin{tabular}{|l|c|}
\hline \multicolumn{1}{|c|}{ State } & WEE (Tonnes) \\
\hline Ahmedabad & 3287.5 \\
\hline Bangalore & 4648.4 \\
\hline Chennai & 4132.2 \\
\hline Delhi & 4730.3 \\
\hline Hyderabad & 2833.5 \\
\hline Kolkata & 4025.3 \\
\hline Mumbai & 11017.1 \\
\hline Nagpur & 1768.9 \\
\hline Pune & 2584.2 \\
\hline Surat & 1836.5 \\
\hline
\end{tabular}

The main sources of e-waste in India are the government, public and private (industrial) sectors, which account for almost 70 per cent of total waste generation. The contribution of individual households is relatively small at about 15 per cent; the rest being contributed by manufacturers. Though individual households are not large contributors to waste generated by computers, they consume large quantities of consumer durables and are therefore, potential creators of waste. An Indian market Research Bureau (IMRB) survey of 'E-waste generation at Source' in 2009 found that out of the total e-waste volume in India [40], televisions and desktops including servers comprised 68 per cent and 27 per cent respectively. Imports and mobile phones comprised of 2 per cent and 1 per cent respectively.

\subsection{E-waste Imports}

In 2009, India generated a Press Release titled “The e-waste industry in India: CSE exposes what lies beneath", published by the Centre for Science and Environment, New Delhi. As of 2010, 5.9 million tonnes of hazardous waste were produced domestically and imported 6.4 million tonnes. It generates about 3,50,000 tonnes of electronic waste every year and imports another 50,000 tonnes.

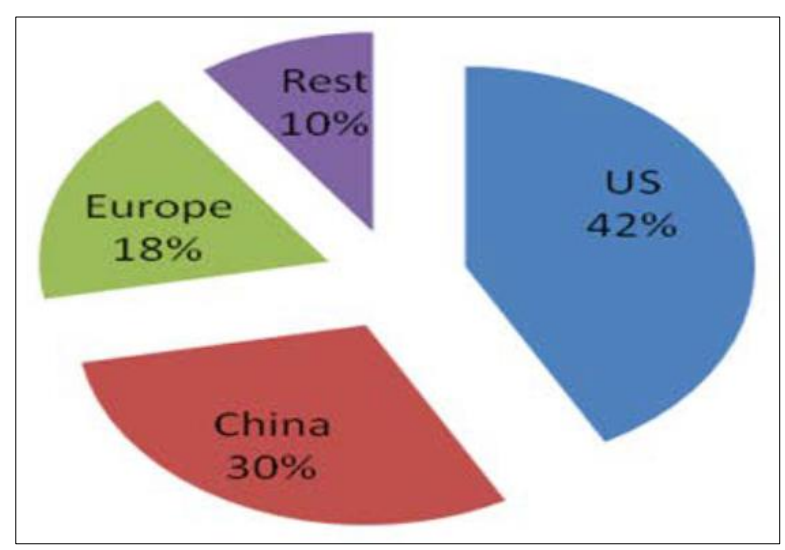

Figure 1 Percentage of Hazardous E-waste Imported from various countries to India 
Looking at the country-wise share in India's e-waste imports, US has a maximum share of around $42 \%$, China at around $30 \%$ followed by Europe at around 18\% and rest 10\% is from other countries like Taiwan, South Korea, Japan etc (Figure 1). Developed countries export their e-wastes to developing countries like India with no regard for environmental or worker health and safety. The major reasons are cheap labour [41] (US - \$30/ computer, India - \$2/ computer, savings - \$28/ computer), weak environmental laws and lack of occupational standards in the country.

Like other Asian countries, India has also felt the pressure from the developed countries to liberalize its import rules to allow access to its markets for their re- manufactured goods. It is argued by the countries like U.S., Switzerland and Japan that promoting trade in re-manufactured goods helps both the developed and the developing countries by increasing access to low cost, superior quality products while helping solid waste management and encouraging transfer of technology and skills. But India is apprehensive that it could lead to a deluge of import of low-quality cheap goods and actually amount to transfer of waste from the developed to the developing countries

Some provisions contained in some specific policies enable import of e-waste. For instance, India's export-import (EXIM) policy allows import of the second-hand computers not more than 10 years old, besides letting computers in as donations. The Foreign Trade (Development and Regulation) Act, 1992 provides for import of computers and peripherals from zones, which have been set up primarily for export, i.e. EOU (Export Oriented Units), EPZ (Exports Processing Zones), STP (Software Technology Parks) and EHTP (Electronics Hardware Technology Parks) at a zero custom duty. These computers can be donated to the recognized non-commercial educational institutions, registered charitable hospitals, public libraries, public-funded research and development establishments and organizations of the Government of India and State/ UT Governments.

Moreover, there is no EXIM code for trade in second-hand computers for donation purpose or for resale. Both secondhand and new computers are placed under the same EXIM code in the Indian Customs Tariff Act allowing exporters to club new computers with the old ones. Besides, the Directorate-General of Foreign Trade (DGFT) rules are flexible to interpretation enabling the Customs Authorities to take on- the- spot decisions and provide rules exemption. Thus, if a consignment of second-hand computers is found without a license, traders manage to get their shipment released by paying a penalty. Importers also escape full penalty by an under-assessment of illegally imported goods [42].

Among all ports, the Mumbai Port Trust and the Jawaharlal Nehru Port Trust have been found to have the largest amount of hazardous goods lying around. Much of the global waste which is imported into India and finds their way into the ports is labelled as waste or mixed waste paper consignments. Of the 12 major ports and 14 intermediate ports in India, the Jawaharlal Nehru Port at Nhava Sheva has two scanning machines. It is the largest port in India, handling close to 50 per cent of the country's port traffic.

\subsection{E-Waste Economy in the Unorganized Sector}

The unorganized sector mainly consists of the urban slums of the metros and mini-metros, where recycling operations are carried out by the unskilled employees, using the most rudimentary methods to reduce cost. A study by the Basel Action Network (BAN) in partnership with Toxic Link reveals that e-waste is received and processed in India in similar manner as is done in China, or the condition could be even worse. The unorganised sector consists of an assortment of small and informal businesses not governed by any stringent health and environmental regulations.

In India, the informal recycling sector employs mostly unskilled migrant labor and those from marginalized groups. Most migrants come from poorer Indian states such as Uttar Pradesh, Bihar, Orissa and West Bengal or are immigrants from neighboring countries such as Bangladesh. Women and children also constitute a significant proportion of the workforce. Most people involved in informal recycling are the urban poor with low literacy levels, and hence have very little awareness regarding the hazards of E-waste and the recycling processes.

\subsection{E-waste Economy in the Organized Sector}

In July 2009, organized recyclers formed the E-waste Recycler's Association (ERA) but facing stiff competition from the unorganized sectors, they have been able to capture only 10 per cent of the total share of the e-waste market. A problem facing the organized sector is the lack of proper collection and disposal mechanisms and appropriate technologies in the face of a large informal sector [43]. Due to lack of proper collection systems, households and institutions at times end up storing obsolete products in their warehouses or storerooms. Even when these are sold or exchanged, they are refurbished and then resold.

Only a small proportion of obsolete electronics products actually find its way into the e-waste processing stream. This is the dilemma facing the 10,000 sq. $\mathrm{ft}$. formal e-waste dismantling unit in Noida (Uttar Pradesh) belonging to the TIC 
Group India Pvt. Ltd, which can process up to 500 tonnes of e-waste annually. But since June 2008, when it was launched, the unit has processed only 200 tonnes. Similarly, the Attero recycling unit in Roorkee (Uttarakhand) is a $35 \mathrm{crore}$ plant which can process 36,000 tonnes of waste in a year although it is getting only 600 tonnes currently.

The formal sector also lack refineries for precious metals recovery. Therefore, according to the ERA, the only way to sustain formal business in the current scenario is the license to import. Currently, the Attero recycling unit is the only recognized recycling facility for e-waste in India, which has the license to import e-waste from the developed countries. Applications from other formal agencies are pending with the Ministry of Environment and Forests, Government of India.

The formal sector accounts for less than 10 per cent of the recycling business, so there is huge scope for growth as the recyclers and suppliers are engaging with IT giants and other enterprises to dispose e-devices efficiently.The informal E-waste sector is well networked but unregulated [44]. The financial flow in the sector is highly organized and the huge network of collectors, traders and recyclers make financial gain through re-use, refurbishment and recycling. The low infrastructure set-up and operational costs enable them to make profit and dominate the market. There each player in the trade value chain makes at least a 10 per cent profit. The size of the informal sector continues to grow.

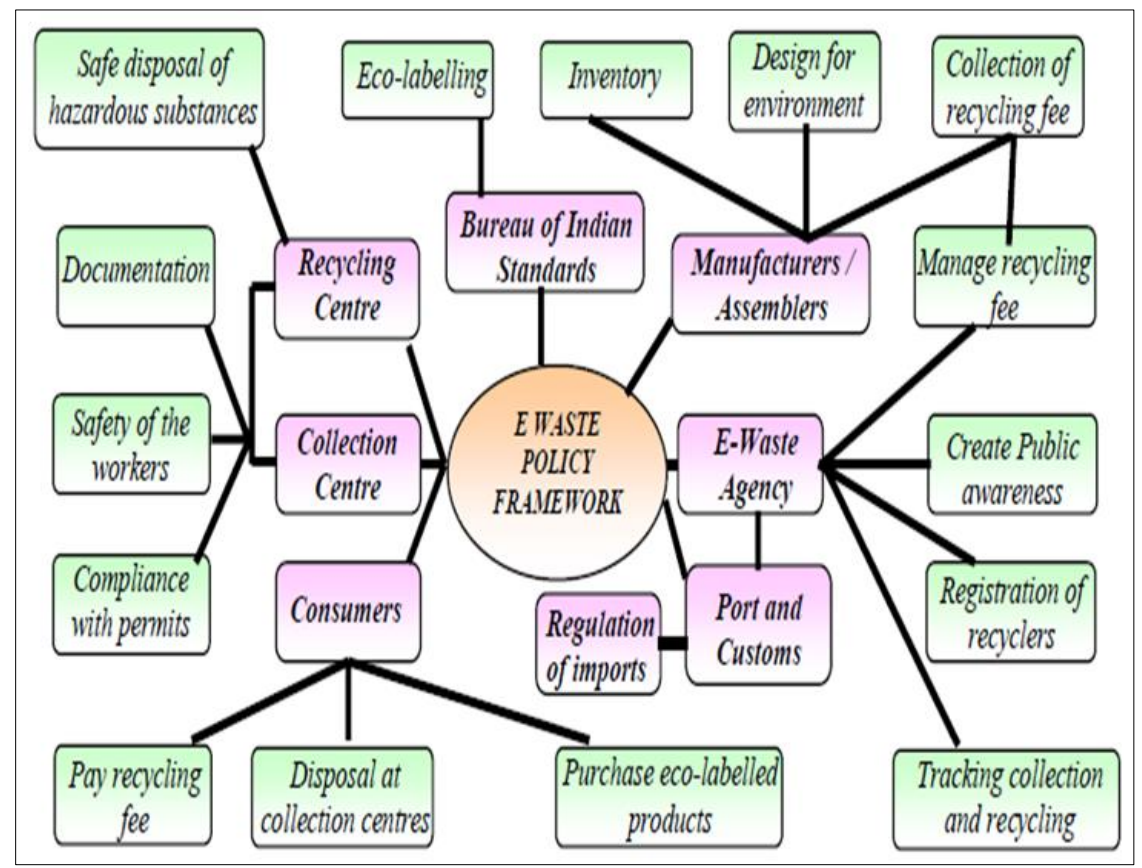

Figure 2 Schematic Diagram of E-Waste management in India

\section{Environmental and health hazards of E-waste}

\subsection{Impacts of E-waste}

The impacts of e-waste are many. When released into the atmosphere, practically every living organism is impacted negatively. Anything that comes in to contact with improperly managed e-waste is at risk. Large amounts of e-waste material and process residues never get recycled and are simply dumped in open fields; along riverbanks, ponds, and wetlands; in rivers; and in irrigation ditches. Indiscriminate dumping and even landfills have exacerbated contamination of drinking water sources. Further, when simply dumped in open fields, the soil becomes polluted contaminating crops, herbs, plants, shrubs trees and grasses. When e-waste is burnt or incinerated, it releases fumes, fly ash and fine particles containing dangerous toxins in to the air, inhalation of which adversely affect human and animal life.

Recyclable e-waste is characterized as a commodity, while e-waste that cannot be reused is distinguished as waste. Both types of e-waste have raised concerns considering that many components of such equipment are toxic and nonbiodegradable. E-wastes that are landfilled produce contaminated leachates, which eventually pollute the ground water. 
Acids and sludge produced from melting computer chips, if disposed on the ground, causes acidification of the soil. Incineration of e-wastes can emit toxic fumes and gases, thereby polluting the surrounding air.

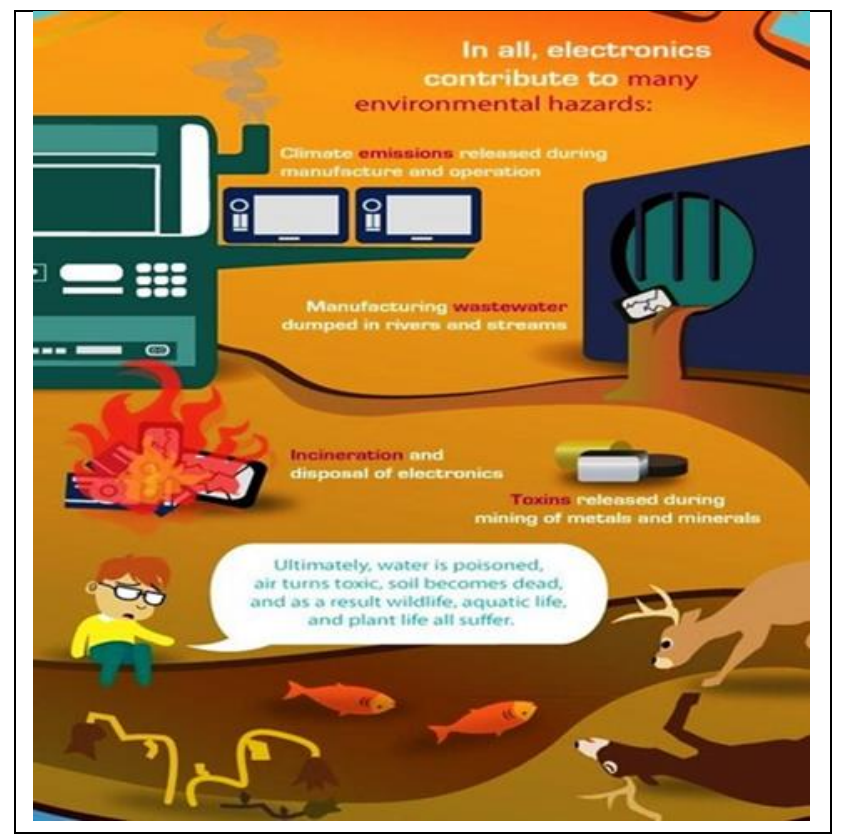

Figure 3 Environmental hazards of improper E-waste Disposal

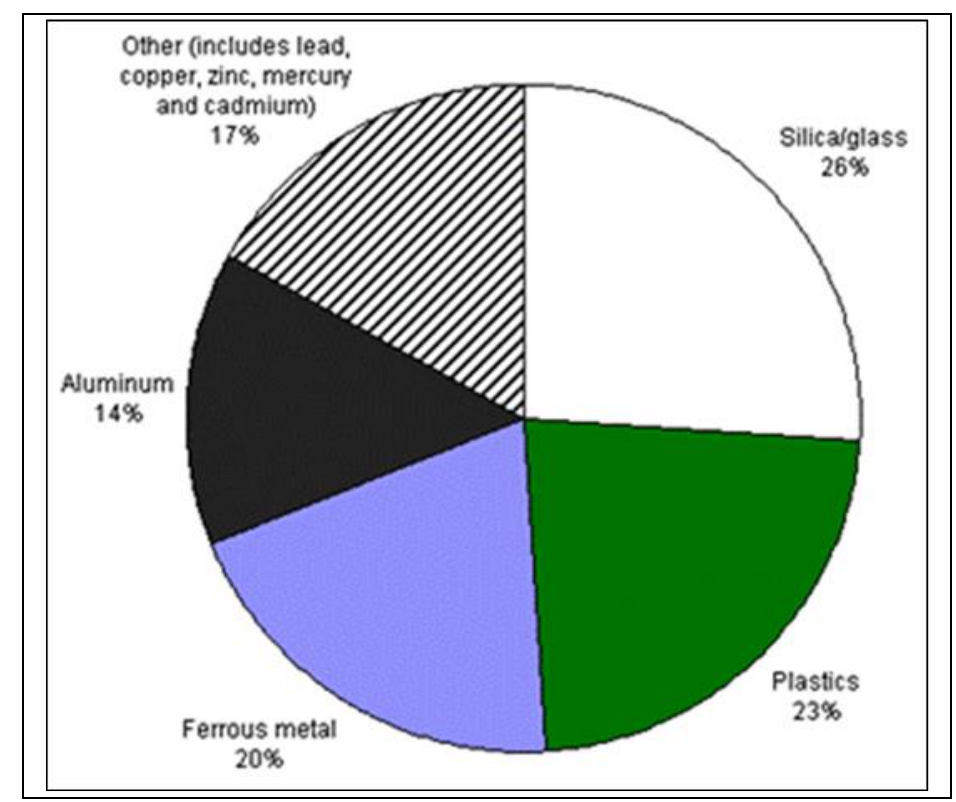

Figure 4 Chemical Components in a Computer

\section{Toxic Constituents of E-waste}

E-waste contains over 1000 different substances, many of which are toxic, creating serious pollution upon disposal. Electronic scrap components, such as CPUs and Cathode ray tubes found in televisions and computer monitors, contain potentially harmful components such as lead, mercury, cadmium, beryllium and brominated flame retardants. A mobile phone/ smart phone contains more than 50 different components, including base metals (such as copper, tin), special non-ferrous metals (such as cobalt, indium, and antimony) and precious metals (such as silver, gold, palladium). The presence of elements like lead, mercury, arsenic, cadmium, selenium, hexavalent chromium, and flame retardants 
beyond threshold quantities, make e-waste hazardous in nature [45]. Obsolete computers pose the most significant environmental and health hazard among the e-wastes (Fig $2 \& 3$ ).

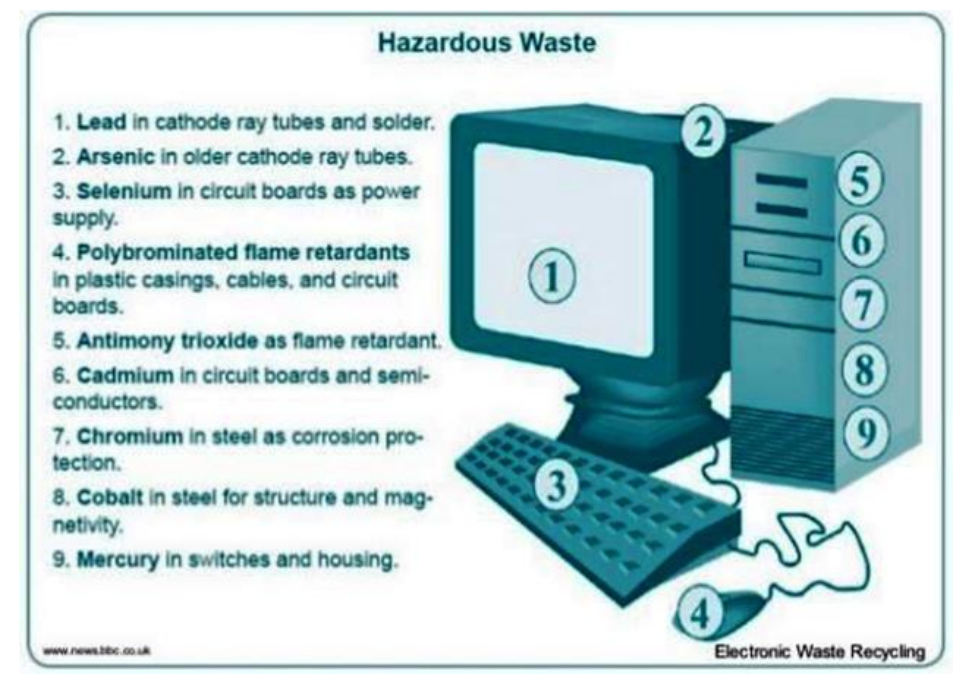

Figure 5 Toxic components in a PC

Table 3 Deleterious effects of various pollutants from E-waste on the human body

\begin{tabular}{|c|c|c|}
\hline E-Waste Component & Products in which Used & Adverse Health Effects \\
\hline Americium & $\begin{array}{l}\text { The radioactive source in smoke } \\
\text { alarms. }\end{array}$ & Carcinogenic. \\
\hline Lead & $\begin{array}{l}\text { Solder, CRT monitor glass, lead- } \\
\text { acid batteries, PVC. A typical 15- } \\
\text { inch cathode ray tube may contain } \\
1.5 \text { pounds of lead. }\end{array}$ & $\begin{array}{l}\text { Impaired cognitive function, behavioral } \\
\text { disturbances, attention deficits, } \\
\text { hyperactivity, conduct problems, and } \\
\text { lower IQ. These effects are most damaging } \\
\text { to children. }\end{array}$ \\
\hline Mercury & Flat screen monitors. & $\begin{array}{l}\text { Sensory impairment, dermatitis, memory } \\
\text { loss, and muscle weakness. Exposure in } \\
\text { utero causes fetal deficits in motor } \\
\text { function, attention, and verbal domains. }\end{array}$ \\
\hline Cadmium & $\begin{array}{l}\text { Found in light-sensitive resistors, } \\
\text { corrosion-resistant alloys for } \\
\text { marine and aviation } \\
\text { environments, a and nickel- } \\
\text { cadmium batteries. ecosystem. }\end{array}$ & $\begin{array}{l}\text { Severe damage to the lungs and is also } \\
\text { known to cause kidney damage. Cadmium } \\
\text { is also associated with deficits in } \\
\text { cognition, learning, behavior, and } \\
\text { neuromotor skills in children. }\end{array}$ \\
\hline Sulphur & Found in lead-acid batteries. & $\begin{array}{l}\text { Health effects include liver damage, } \\
\text { kidney damage, heart damage, eye and } \\
\text { throat irritation. }\end{array}$ \\
\hline $\begin{array}{l}\text { Brominated Flame } \\
\text { Retardants (BFRs) }\end{array}$ & $\begin{array}{l}\text { Used as flame retardants in } \\
\text { plastics in most electronics. }\end{array}$ & $\begin{array}{l}\text { Impaired development of the nervous } \\
\text { system, thyroid problems, liver problems. }\end{array}$ \\
\hline Beryllium oxide & $\begin{array}{l}\text { Filler in thermal interface } \\
\text { materials such as thermal } \\
\text { grease used in heatsinks for CPUs, } \\
\text { gas lasers, magnetrons, and heat } \\
\text { transfer fins in vacuum tubes. }\end{array}$ & $\begin{array}{l}\text { Occupational exposures associated with } \\
\text { lung cancer, other common adverse health } \\
\text { effects are beryllium sensitization, } \\
\text { chronic beryllium disease, and acute } \\
\text { beryllium disease. }\end{array}$ \\
\hline
\end{tabular}


E-Waste contains a number of toxic components that can cause serious widespread damage to the environment, vegetation and human as well as animal health if not properly discarded in an environmentally sound manner. Table 1 shows the various health hazards associated with pollutants from e-waste.

Great care must be taken to avoid unsafe exposure in recycling operations and leaking of materials such as heavy metals from landfills and incinerator ashes. The recycling of hazardous substances contained in CRTs, capacitors, batteries and Liquid Crystal Displays is critical and poses serious health risks and environment dangers of not properly handled. There is a release of highly toxic dioxins and furans when e-waste is incinerated. If the CRT is crushed and burned, it emits toxic fumes into the air [46]. Landfills can lead to the leaching into the ground water, contaminating drinking water. The cadmium from one mobile phone battery is enough to pollute $600 \mathrm{~m} 3$ of water. Table 2 gives the impact of recycling if different e-waste components.

Table 4 The Environmental Impact of Processing of Different Electronic Waste Components

\begin{tabular}{|c|c|c|}
\hline E-Waste Component & Process Used & Potential Environmental Hazard \\
\hline $\begin{array}{l}\text { Cathode ray tubes (used in TVs, } \\
\text { computer monitors, ATM, video } \\
\text { cameras, and more) }\end{array}$ & $\begin{array}{l}\text { Breaking and removal } \\
\text { of yoke, then dumping }\end{array}$ & $\begin{array}{l}\text { Lead, barium and other heavy metals } \\
\text { leaching into the ground water and release } \\
\text { of toxic phosphor }\end{array}$ \\
\hline $\begin{array}{l}\text { Printed circuit board (image } \\
\text { behind table - a thin plate on } \\
\text { which chips and other electronic } \\
\text { components are placed) }\end{array}$ & $\begin{array}{l}\text { De-soldering and } \\
\text { removal of computer } \\
\text { chips; open burning and } \\
\text { acid baths to remove } \\
\text { metals after chips are } \\
\text { removed. }\end{array}$ & $\begin{array}{l}\text { Air emissions and discharge into rivers of } \\
\text { glass dust, tin, lead, brominated dioxin, } \\
\text { beryllium cadmium, and mercury }\end{array}$ \\
\hline $\begin{array}{l}\text { Chips and other gold plated } \\
\text { components }\end{array}$ & $\begin{array}{l}\text { Chemical stripping } \\
\text { using nitric and } \\
\text { hydrochloric acid and } \\
\text { burning of chips }\end{array}$ & $\begin{array}{l}\text { PAHs, heavy metals, brominated flame } \\
\text { retardants discharged directly into rivers } \\
\text { acidifying fish and flora. Tin and lead } \\
\text { contamination of surface and groundwater. } \\
\text { Air emissions of brominated dioxins, heavy } \\
\text { metals, and PAHs }\end{array}$ \\
\hline $\begin{array}{l}\text { Plastics from printers, keyboards, } \\
\text { monitors, etc. }\end{array}$ & $\begin{array}{l}\text { Shredding and low temp } \\
\text { melting to be reused }\end{array}$ & $\begin{array}{l}\text { Emissions of brominated dioxins, heavy } \\
\text { metals, and hydrocarbons }\end{array}$ \\
\hline Computer wires & $\begin{array}{l}\text { Open burning and } \\
\text { stripping to remove } \\
\text { copper }\end{array}$ & PAHs released into air, water, and soil. \\
\hline
\end{tabular}

\section{Recycling of E-waste and stake holders}

\subsection{History of Recycling}

E-waste was initially dumped into landfills or incinerated. After realizing the true extent of harm caused by hazardous substances in e-waste, many rules have been introduced regarding the disposal and recycle of e-waste. Proper disposal is crucial to preserving the environment and recovering value for businesses.

Two incidents in the 1980s gave the world a rude awakening. The first episode was the Khain Sea waste disposal incident. A ship that went by the name of Khain Sea, registered in Liberia was carrying close to 14,000 tonnes of toxic ash from incinerated e-waste in Philadelphia, USA. The original destination of the e-waste, New Jersey, refused to take it. This led the ship searching for a place to dump the waste for two years. The crew finally dumped nearly 4,000 tonnes of the ash near Gonaives in Haiti under the pretence of "topsoil fertiliser". The rest of the ash started disappearing en route from Singapore to Sri Lanka. The ship's captain later admitted that the remaining waste, roughly more than about 10,000 tonnes, had been dumped into the Indian and Atlantic Oceans.

A similar incident took place in Koko, Nigeria. Approximately 3,500 tonnes of toxic waste for Italy was dumped in the small town of Koko in 1988. 
These events led to the Basel Convention, 1989 - an international treaty designed to reduce the movements of hazardous waste between nations, and specifically to prevent the transfer of hazardous waste from developed to less developed countries (LDCs).

Since then, recycling plants have opened up around the world, particularly in Asia. Today, we have the technology to make the most out of our e-waste by extracting useful resources from it before disposing of it in a safe manner.

\subsection{Recycling Methods}

\subsubsection{Informal Sector}

Informal sector in India has a historic role in waste management and recycling. It is well known that e-waste recycling is no exception to this with an estimated 95 percent of e-waste being recycled through the informal sector. The informal e-waste recycling sector provides jobs to thousands of people in urban and peri-urban areas, and supports the formal waste management agencies like municipalities. Widespread active network and considerable manual skills enable the informal sector to have profitable e-waste management business. The e-waste recycling in the informal sector essentially involves collection, segregation, dismantling. There are extensive repair and refurbishment activities resulting in an extended life of the products and a large second-hand market, in particular for IT products. To a large extent, the informal sector in India is also involved in extraction of precious metals. These generally small units exercise little or no control over their activities and use highly-polluting process - in many cases without being aware of the risks of these.

\subsubsection{Formal Sector}

Formal e-Waste recyclers with now rising e-waste quantities on one hand, and with new regulatory requirement entering into force soon on the other hand, increasingly enter the e-waste recycling sector. There is a widespread expectation that these formal sector recyclers would be able to manage e-waste in an environmentally sound manner by using Best Available Technologies (BAT) leading to better environmental management and enhanced resource recovery. However, it is not clear whether the advent of formal recycling would come at the expense of informal sector recyclers or would complement their activities.

\subsection{Challenges of Recycling}

One of the major challenges is recycling the printed circuit boards (PCB) from the electronic wastes. The circuit boards contain such precious metals as gold, silver, platinum, etc. and such base metals as copper, iron, aluminium, etc. One way e-waste is processed is by melting circuit boards, burning cable sheathing to recover copper wire and open- pit acid leaching for separating metals of value. Conventional method employed is mechanical shredding and separation but the recycling efficiency is low. Alternative methods such as cryogenic decomposition have been studied for printed circuit board recycling. Properly disposing of or reusing electronics can help prevent health problems, reduce greenhouse-gas emissions, and create jobs [47]. Reuse and refurbishing offer a more environmentally friendly and socially conscious alternative to down cycling processes.

\subsection{E-waste Recycling Practices in India}

Most e-waste is not recycled, because e-waste items tend to go out with household waste and receive no special treatment. Most e-waste is currently disposed in landfills. In India, E-waste is recycled in Delhi, several states around Delhi, Chennai, Bangalore, Pune, and Kolkata. Delhi acts as the centre of E-waste recycling in the country. In the Mandoli Industrial Area in Delhi, residents engage in illegal recycling of PCBs using acid bath processes to recover copper and gold.

According to a study, ninety-five percentage of the E-waste in India is being recycled by informal sector and five percentage of the E-waste by formal sector. This is because businesses sell their discarded IT and other equipment to informal recyclers for quick money without realizing the hazardous implications it causes to health and environment. Currently, in India, there are over 2000 units engaged in non formal sector for E-waste recycling. Non-formal units have lack of knowledge of the processes of smelting/ reprocessing and, therefore, prefer to sell such scrap. Thus, they play an important role in proper recycling of a large quantum ( > 95\% by weight) of e-waste in reuse chain without harming environment [48].

Formal Sectors are facing problem of not having sufficient input materials. There are only two Authorised Treatment Facility (ATF) related to e-waste present in the country, each of them having a full capacity of around five tonnes per day. These facilities are authorised to recycle e-waste or WEEE in the country. According to MoEF, there are only two e- 
waste dismantling facilities in formal sector in India. These facilities are M/s. Trishiraya Recycling facilities, Chennai and M/s E-Parisara, Bangalore.

\subsection{Stake Holders}

The main stakeholders in e-waste generation and management are the manufacturers, distributors/importers, refurbishment centres, consumers, collectors, recyclers, policy makers and policy implementers. These diverse stakeholders are significant right from the production of Electrical and Electronic Equipment (EEE) to the final disposal of E-waste. Identifying the range of stakeholders in the E-waste management system and constructing a sustainable Ewaste management system involving these stakeholders are the needs of the hour [46].

\subsubsection{Roles and Responsibilities of Various Stakeholders in the Ecosystem}

The various stakeholders in the system have clear roles to play and to act in a synergistic manner as given in the table below:

Table 5 Roles and Responsibilities of Stakeholders in the Ecosystem

\begin{tabular}{|c|c|c|}
\hline Ser No & Role & Responsibility \\
\hline 1. & $\begin{array}{l}\text { Generator of } \\
\text { e-waste }\end{array}$ & $\begin{array}{l}\text { To dispose of e-waste to the authorised dealer/ PRO. } \\
\text { Corporate users to maintain records of e-waste and donations made. } \\
\text { Individual companies and public bodies need to file returns to show their } \\
\text { disposal practice }\end{array}$ \\
\hline 2. & $\begin{array}{l}\text { Producer } \\
\text { Responsibility } \\
\text { Organisation } \\
\text { (PRO) }\end{array}$ & $\begin{array}{l}\text { Responsible for the collection, storage and recycling of the E-waste through its } \\
\text { network of empanelled dealers, collectors and recyclers. } \\
\text { Incentivise customers from the revenue generated, as per the type of product. } \\
\text { Maintain annual records of e-waste generated, per product, quantity and brand. } \\
\text { Monitor its network of dealers, collectors and recyclers for proper, accurate and } \\
\text { timely reporting. }\end{array}$ \\
\hline 3. & $\begin{array}{l}\text { Existing } \\
\text { informal } \\
\text { sector }\end{array}$ & $\begin{array}{l}\text { Potential to be part of the storage and collection process. } \\
\text { Skill up-gradation to enable their participation in dismantling and recycling } \\
\text { processes. } \\
\text { Be part of the formal ecosystem through registrations with the concerned } \\
\text { pollution control boards, by following environmentally friendly and scientific } \\
\text { methods of managing e-waste. }\end{array}$ \\
\hline 4. & Recyclers & $\begin{array}{l}\text { Become members of a PRO. } \\
\text { To employ authorized technologies for dismantling and recycling. } \\
\text { To maintain proper environmental and health standards. } \\
\text { To maintain and produce records to PROs. }\end{array}$ \\
\hline 5. & Regulators & $\begin{array}{l}\text { To frame appropriate guidelines/legislation to support the model } \\
\text { To monitor the processes regularly } \\
\text { To provide incentives to entrepreneurs to set up facilities. } \\
\text { To regulate/control the number of facilities in a geographical area. } \\
\text { To approve technologies. } \\
\text { To form multi-stakeholder monitoring committee. } \\
\text { To create awareness among generators of waste. }\end{array}$ \\
\hline
\end{tabular}

\section{Principles of E-waste management}

\subsection{Recycling}

Recycling raw materials from "end-of-life" electronics is the most effective solution to the growing e-waste problem. Most electronic devices and their parts contain a variety of materials, including metals that can be recovered for future 
uses. By dismantling and providing reuse possibilities, intact natural resources are conserved and air and water pollution caused by hazardous disposal is avoided. Additionally, recycling reduces the amount of greenhouse gas emissions caused by the manufacturing of new products.

Another benefit of recycling e-waste is that many of the materials can be recycled and re-used again. Materials that can be recycled include ferrous (iron-based) and non-ferrous metals, glass, and various types of plastic. Non-ferrous metals, mainly Aluminum and Copper can all be re-smelted and re-manufactured. Ferrous metals such as steel and iron can be also being re-used. Due to the recent surge in popularity in 3D printing, certain 3D printers have been designed (FDM variety) to produce waste that can be easily recycled which decreases the amount of harmful pollutants in the atmosphere.

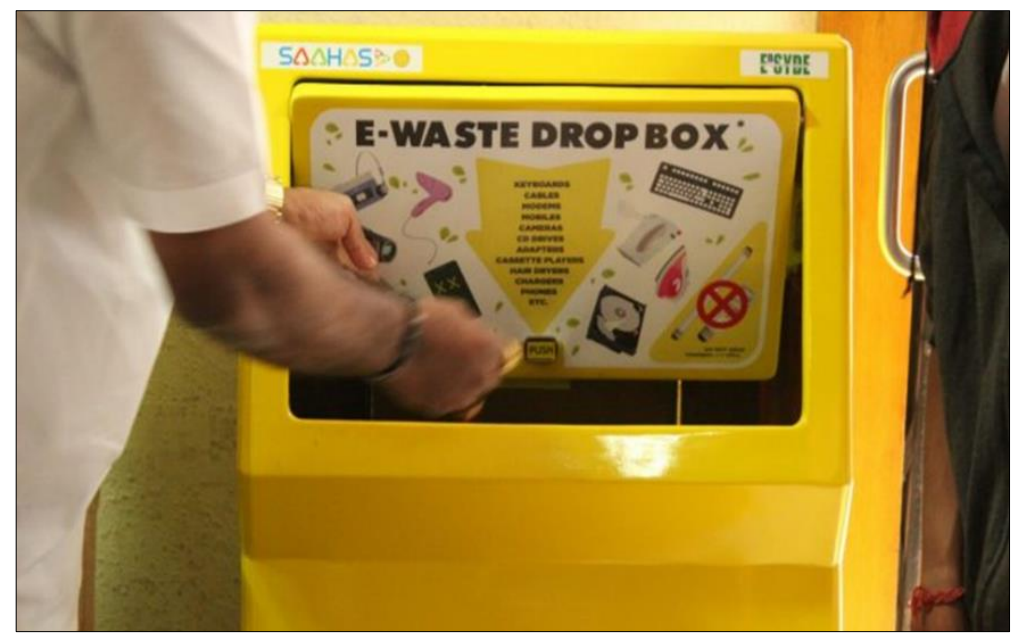

Figure 6 E-waste drop box at MG road Bengaluru, designed by an NGO

The excess plastic from the printers that comes out as a by product can also be reused to create new 3D printed creations. There are various laws which directly or indirectly deal with hazardous wastes and toxic substances. One of them is the Environmental (Protection) Act, 1986, which comprehensively deals with environmental problems. Section 6 expressly empowered the Central Government to make rules on various items including the procedures and safeguards for the handling of hazardous substances and the prohibition and restriction on the handling of hazardous substances in different areas.

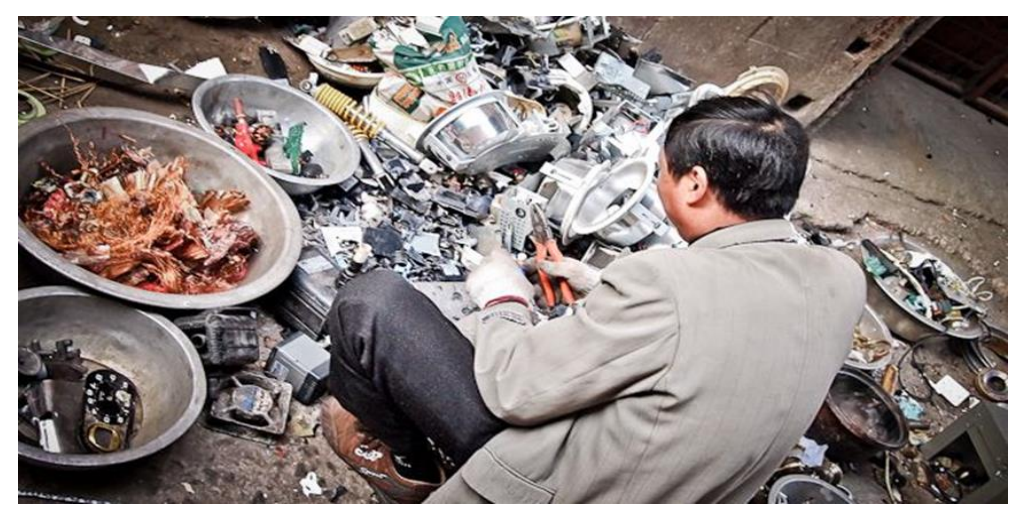

Figure 7 Recycling of E-waste

\subsection{Landfill Disposal}

Irrespective of the current global move towards zero wastes, the number of landfills has been increasing in both developed and developing countries. While the owners of modern landfills argue that recently constructed landfills are capable of safely isolating from the environment the pollutants found in electronics, the presence of thousands of old landfills with no barrier and containing a mixture of putrescible and e-wastes is of much concern. There is sufficient evidence now to demonstrate that landfills accepting electronic devices or old landfills containing e-wastes will cause groundwater contamination [36]. Pollutants have the potential to migrate through soils and groundwater within and 
around landfill sites. Leachates can contain high concentrations of dissolved and suspended organic substances, inorganic compounds and heavy metals. However, the concentrations of toxic substances from leachate depend on the waste characteristics and stages of waste decomposition in a particular landfill.

One measure designed to assess the potential toxicity of leachates from e-waste disposal is Toxicity Characteristic Leaching Procedure (TCLP) which simulates landfill leaching in terms of a worst case eventuality. A number of electronic devices were subjected to tests by laboratory based TCLP. TCLP test helps to determine if a solid waste processes physical and chemical properties that make it a toxicity characteristic (TC) hazardous waste. Electronic devices are considered to be TC hazardous waste under provision of the Resource Conservation and Recovery Act (RCRA) if the devices contain specific elements higher than TC regulated concentrations [33, 34].

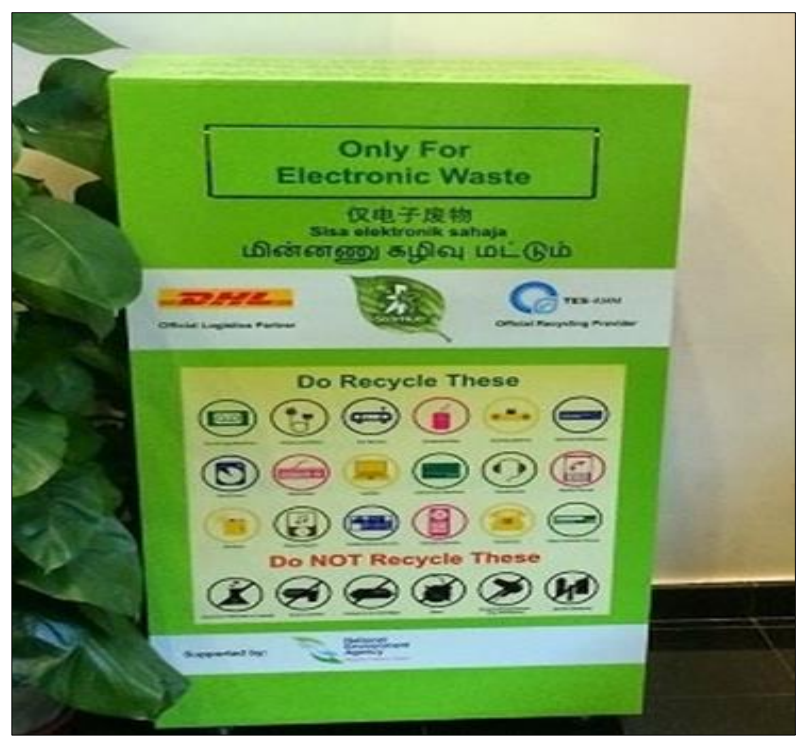

Figure 8 Disposal Bins for E waste

\subsection{Life Cycle Assessment (LCA)}

Life Cycle Assessment is a tool used to design environmentally friendly electronic devices and to minimise e-waste problems. Since the 1990s considerable research has been conducted on the LCA of electronic devices in terms of ecodesign, product development and environmental impacts. The published reviews show the necessity of having more consideration in the design of electronic devices to take account of environmental and economic impacts. An environmentally friendly design is a better alternative product and it may in turn appeal to consumers. LCA is a powerful tool for identifying potential environmental impacts to develop eco-design products such as printers, desktop personal computers, heating and air conditioner devices, washing machines. It is also a systematic tool to define many environment impact categories such as carcinogens, climate change, ozone layer, Eco-toxicity, acidification, eutrophication and land use, to improve the environmental performance of products.

LCA is widely used for e-waste management as it estimates the effects of materials consumption, conducts assessment of eco-design and product development, allocates the impacts of the examined product or process of environmental interest and takes better decisions regarding e-waste disposal.

\subsection{Material Flow Analysis (MFA)}

Before the Basel Convention came into force, large volumes of e-waste from developed countries were exported for reuse or recycling in developing countries especially China, India and South Africa. MFA is a tool used to study the route of material (e-waste) flowing into recycling sites, or disposal areas and stocks of materials, in space and time. It links sources, pathways, and the intermediate and final destinations of the material. Material Flow Analysis is a decision support tool for environmental and waste management. This tool can be applied to develop appropriate e-waste management. This includes a consideration of the flow of e-waste and its assessment it in terms of environmental, economic and social values. A study used MFA to investigate the flow of e-waste in Asia [47]. They found that second hand electronic devices from Japan are reused in Southeast Asia (e.g., Vietnam and Cambodia) while most of the e-waste is recycled in Gangdong Province, China, where improper recycling methods were being used. 
MFA helps in investigating the flow of e-waste, estimating e-waste generation and is thus used for environmental decision making.

\subsection{Multi Criteria Analysis (MCA)}

MCA is a decision-making tool developed for considering strategic decisions and solving complex multi-criteria problems that include qualitative/quantitative aspects of the problem. MCA models have been applied to environmental problems, including those of e-waste management, to provide optional e-waste management strategies. For example, a study used MCA to select the best location for e-waste recycling plants in Spain. The study was based on quantitative criteria, specifically the economics of warehouse locations.

Although, MCA is not widely used for e-waste management, it is commonly used for solid waste and hazardous waste management. MCA has been recommended for social response to e-waste management and to this end it is a useful tool in combination with other tools being used for e-waste management.

\subsection{Extended Producer Responsibility (EPR)}

EPR is an environment policy approach that attributes responsibility to manufacturers in taking back products after use, and is based on polluter-pays principles. Leaders of EPR programs for e-waste management are the advanced nations, including the European Union (EU), Switzerland, Japan and some states of the United States and Canada. The Organisation for Economic Cooperation and Development (OECD) has supported an environmentally friendly program and published a guidance manual for governments. This solves e-wasteproblems on a national scale and enforces producers based on polluter-pays principle.

\section{E-waste (management) rules, 2016 - An overview}

\subsection{Introduction}

Looking to growing problems of e-waste, the Central Government in the exercise of the powers provided under Sections 6, 8 and 25 of the Environment (Protection) Act, 1986 has notified these rules. E-Waste (Management) Rules, 2016 supersede the E-Waste (Management and Handling) Rules, 2011. It consists of 24 rules divided in Six Chapters and four Schedules. The rules aim to enables the recovery and/or reuse of useful material from e-waste, thereby reducing the hazardous wastes destined for disposal and to ensure the environmentally sound management of all types of waste of electrical and electronic equipment. These rules shall come into force from 01 Oct 2016.

These rules shall apply to every producer, consumer and bulk consumer, manufacturer, collection centres, dealers, eretailer, refurbisher, dismantler and recycler involved in the manufacture, sale, purchase and processing of electrical and electronic equipment, including their components, consumables, parts and spares which make the product operational but shall not apply to-

- Used lead acid batteries as covered under the Batteries (Management and Handling) Rules, 2001 made under the Act;

- Micro enterprises as defined in the Micro, Small and Medium Enterprises Development Act, 2006 (27 of 2006 );

- Radio-active wastes as covered under the provisions of the Atomic Energy Act, 1962 (33 of 1962) and Rules made there under.

\subsection{Responsibilities}

The responsibilities of the manufacturer, producer, collection centers, dealers, refurbisher, consumer/bulk consumer, dismantler and recycler in relation to e-waste management are the subject matter of Rules 4 to 12.

\subsection{Responsibilities of Manufacturer}

- The manufacturer shall be responsible to collect e-waste generated during the manufacture of any electrical and electronic equipment and channelize it for recycling or disposal;

- The manufacturer shall ensure that no damage is caused to the environment during storage and transportation of e-waste and also file annual returns to the concerned State Pollution Control Board on or before the 30th day of June. 


\subsection{Responsibilities of Producer}

- The producer shall be responsible for the collection of e-waste generated from the 'end of life' of their products and channelizing it for recycling or disposal. And to ensure that such e-waste are channelized to registered dismantler or recycler.

- The import of electrical and electronic equipment shall be allowed only to producers having Extended Producer Responsibility-Authorization and also filing annual returns to the Central Pollution Control Board on or before $30^{\text {th }}$ June of following financial year.

- The producer shall also be responsible for providing contact details such as address, telephone numbers/helpline numbers to consumer(s) or bulk consumer(s) so as to facilitate return of used electrical and electronic equipment.

- Further, the producer shall be responsible to create awareness among consumers or bulk consumers with regard to hazardous constituents, hazards of improper handling and improper recycling of e-waste and instructions for handling the equipment after its use along with do's and don'ts.

\subsection{Responsibilities of Collection Centres}

- The collection centres are responsible to collect e-waste on behalf of producer or dismantler or recycler or refurbisher.

- The collection centre shall also ensure that e-waste collected by them is stored in a secured manner and no damage is caused to the environment during storage and transportation.

- The collection centre shall file annual return to State Pollution Control Board on or before the $30^{\text {th }}$ day of June and also maintain the records of the e-waste.

\subsection{Responsibilities of Dealers}

- The dealer shall collect the e-waste by providing the consumer a box, bin or a demarcated area to deposit ewaste, or through take back system and send the e-waste so collected to collection centre or dismantler or recycler. The dealer or e-retailer shall refund the amount as per take back system to the depositor of e-waste.

- Every dealer shall ensure that the e-waste thus generated is safely transported to auth dismantlers or recyclers and no damage is caused to the environment during storage and transportation of e-waste.

\subsection{Responsibilities of the Refurbisher}

- Refurbisher is responsible to collect e-waste generated during the process of refurbishing and channelise the e-waste to authorised dismantler or recycler through its collection centre.

- The refurbisher shall ensure that no damage is caused to the environment during storage and transportation of e-waste, processing does not have any adverse effect on the health and the environment and also ensure that the e-waste thus generated is safely transported to authorized collection centres or dismantlers or recyclers.

- The refurbisher shall also file annual returns to the concerned State Pollution Control Board, on or before the 30thJune following the financial year.

\subsection{Responsibilities of Consumer and Bulk Consumer}

Consumer and Bulk Consumer shall ensure that e-waste generated by them is channelized to authorized collection centre or registered dismantlers or recyclers or returned to the pick up or take back services provided by the producers and also shall maintain the records of e-waste generated by the bulk consumer.

\subsection{Responsibilities of Dismantler}

- Every dismantler shall obtain authorization and registration from the State Pollution Control Board.

- Also the dismantler shall ensure that no damage is caused to the environment during storage and transportation of e-waste, no adverse effect on health and environment.

- Also the dismantling processes shall be in accordance with the guidelines published by the Centre Pollution Control Board from time to time.

- The dismantler shall also ensure that non-recyclable or non-recoverable components are sent to authorized treatment storage and disposal facilities. 


\subsection{Responsibilities of Recyclers}

Every recycler shall ensure that the facility and recycling process shall be in accordance with the guidelines of the Central Pollution Control Board from time to time and residue is disposed of in a hazardous waste treatment storage disposal facility.

\subsection{Procedure for Seeking and Grant of Authorization for Management of E-Waste}

Procedure for seeking and grant of authorization for management of e-waste contains under Rules 13 and 14 of the EWaste (Management) Rules, 2016.Every producer, manufacturer, refurbisher, dismantler and recycler of e-waste shall obtain an Extended Producer Responsibility - Authorization or Authorization as the case may be from Central Pollution Control Board (CPCB) or the State Pollution Control Board (SPCB) as the case may be.For getting Extended Producer Responsibility - Authorization or Authorization they shall make an application within a period of 90 days or 120 days as the case may be starting from the date of commencement of the rules to the SPCB or the CPCB.

The SPCB or the CPCB after making enquiry grant an authorization within a period of 120 days and such authorization shall be valid for a period of five years.An application for renewal of Extended Producer Responsibility - Authorization or Authorization shall be made before 120 days from the expiry of given time period (5 years). The SPCB or the CPCB may renew the authorization if there is no violation of rules.

If the holder of authorization has failed to comply with any of the conditions of authorization or the Environment (Protection) Act, 1986, the SPCB, after giving reasonable opportunity to be heard in writing, shall suspend or cancel the authorization for such period, as it considers necessary for public interest and inform CPCB within ten days of cancellation.

\subsection{Procedure for Registration with Central Pollution Control Board or State Pollution Control Board}

Every manufacturer, refurbisher, dismantler or recycler of e-waste shall make an application for the grant or renewal of registration of consent to establish plant and collection centre; certificate of registration issued by the District Industries Centre; proof of installed capacity of plant and machinery issued by District Industries Centre. Such application shall be disposed of within a period of 120 days from the date of receipt of application.

The SPCB after satisfying that the application is complete in all respects and the applicant is utilizing environmentally sound technologies and possess adequate technical capabilities, requisite facilities and equipment to recycle and process e-waste may grant registration. Such registration shall be for a period of 5 years.

Every manufacturer, producer, bulk consumer, collection centre, dealer, refurbisher, dismantler and recycler may store the e-waste for a period of 180 days and also shall maintain a record of collection, sale, transfer, storage and segregation of wastes and make these records available for inspection. There is no time period that has been fixed for inspection.

\subsection{Reduction in the Use of Hazardous Substances in Electrical and Electronic Equipment}

Every producer of electrical and electronic equipment and their components or consumables or parts or spares shall ensure that new electrical and electronic equipment and their components or consumables or parts or spares shall not contain lead, mercury, cadmium, hexavalent chromium, polybrominate biphenyls or polybrominatediphenyl ethers beyond a maximum concentration value of $0.1 \%$ in information technology and telecommunication equipment and consumer electrical and electronic equipment. But the electrical and electronic equipment and their parts placed in the market before $1^{\text {st }}$ May 2014, the restriction of above materials is not allowed. There is no punishment if any producers exceed the concentration fixed under rule 16.

Every producer, dealers, collection centers, refurbishes, dismantlers, recyclers, auctioneers, consumers or bulk consumers shall not import used electrical and electrical equipment in India for use without the compliance of these rules.

The concerned SPCB shall prepare and submit to the CPCB an annual report with regard to the implementation of these rules by the $30^{\text {th }}$ September every year. Also the CPCB shall prepare the consolidated annual review report on management of e-waste and forward it to the Central Government along with its recommendations before the $30^{\text {th }}$ December every year.

Every appeal shall be filled within a period of thirty days from the date on which the order is communicated to aggrieved person to the Appellate Authority comprising of the Environment Secretary of the State. 


\section{Lacunae in implementation of E-waste management}

\subsection{Issues Related to E-Waste in India}

\subsubsection{Volume of E-waste generated}

India stands fifth in e-waste generation producing around 1.7 lakhs metric tonnes per annum.

\subsubsection{Involvement of Child Labor}

In India, about 4.5 lakh child laborers in the age group of 10-14 are observed to be engaged in various E-waste activities and that too without adequate protection and safeguards in various yards and recycling workshops. So, there is an urgent need to bring out effective legislation to prevent entry of child labor into E-waste market- its collection, segregation and distribution.

\subsubsection{Ineffective Legislation}

There is absence of any public information on most SPCBs/PCC websites. Fifteen of the 35 PCBs/PCC do not have any information related to E-waste on their websites, their key public interface point. Even the basic E-waste Rules and guidelines have not been uploaded. In absence of any information on their website, specially on details of recyclers and collectors of E-waste, citizens and institutional generators of E- waste are totally at a loss to deal with their waste and do not know how to fulfill their responsibility. So, there is failure in successful implementation of E-waste Management and Handling Rules, 2012.

\subsubsection{Lack of Infrastructure}

There is huge gap between present recycling and collection facilities and quantum of E-waste that is being generated. No collection and take back mechanisms are in place. There is lack of recycling facilities.

\subsubsection{Health Hazards}

E-waste contains over 1,000 toxic materials, which contaminate soil and ground water. Exposure can cause headache, irritability, nausea, vomiting, and eye pain. Recyclers may suffer liver, kidney and neurological disorders. Due to lack of awareness, they are risking their health and the environment as well.

\subsubsection{Lack of Incentive Schemes}

No clear guidelines are there for the unorganized sector to handle E-waste. Also, no incentives are mentioned to lure people engaged to adopt formal path for handling E-waste. Working conditions in the informal recycling sector are only slightly worse than in the formal sector. No incentive schemes for producers who are doing something to handle ewaste.

\subsubsection{Poor Awareness and Sensitization}

There is limited awareness regarding disposal, after determining end of useful life. Also, only $2 \%$ of individuals think of the impact on environment while disposing off their old electrical and electronic equipment.

\subsubsection{E-waste Imports}

Eighty percent of E-waste in developed countries meant for recycling is sent to developing countries such as India, China, Ghana and Nigeria.

\subsubsection{Reluctance of Authorities}

There is lack of coordination between various authorities responsible for E-waste management and disposal including the non-involvement of municipalities.

\subsubsection{Security Implications}

End of life computers often contain sensitive personal information and bank account details which, if not deleted leave opportunity for fraud. 


\subsubsection{High Cost of Setting up Recycling Facility}

The formal recycling companies in India except some are only limited to pre-processing of the e-waste material, where the crushed e-waste with precious metals is sent to smelting refineries outside India. Formal sector in India still has a long way to go in adopting state - of-art technologies for e-waste recycling due to problems in sourcing e-waste and partly due to difficulty in making it profitable with high end investment in such superior and costly technologies.

\subsubsection{Lack of Research}

Government must encourage research into the development and standards of hazardous waste management, environmental monitoring and the regulation of hazardous waste-disposal.

\section{Challenges \& recommendations for E-waste management}

\subsection{Challenges}

There is a plethora of literature which talks about various challenges that E-Waste Management faces today covering topics like health hazards faced by informal sector workers, absence of robust regulatory framework and many more. Few of them are summarized here with the recommendations for improvement.

\subsubsection{Initial Investment Requirement for Sourcing}

The proper disposal of e- waste is not a matter of importance for most of the organisations, so they are not worried about the method of disposal. They are concerned about the return value of the scrap. Mostly the companies ask for money from recyclers before giving off their end-of-life products. Reaching out to the customers is a huge investment required by these formal recyclers. The logistics is to be provided by the recyclers for the material to be collected and recycled. Thus, for catering to the entire country, presence at nine locations is not enough for these formal recyclers.

\subsubsection{Lack of Supporting Infrastructure}

India doesn't have a smelting unit to extract precious metals from e- waste which are not visible to the eye as in computer processors and this is sent to Belgium and Japan. Shipping it abroad costs a lot of money and around $25 \%$ of the value of extracted metals goes to the foreign companies and India gets the rest. There is no recycler for materials of lamps (CFL bulb, tube light etc.), Ni-Cd batteries, alkaline batteries and dry cell batteries in India. Such materials are either dumped in landfills resulting in loss of resources and contamination of ground water or exported to authorised recyclers in foreign countries resulting in high logistic costs.

\subsubsection{Failure of the EPR Directive}

The Extended Producer Responsibility (EPR) which is part of the E Waste Rules 2011 has been largely left ignored by CPCB. Under EPR, producers of electronic goods are mandated to manage the 'end of life' of goods. Thus, even after consumers discard the electronic goods, the producers are responsible to collaborate with the government to collect ewaste and organize systems to process it scientifically. The CAG report though has noted that CPCB set up a committee to formulate EPR mechanisms only in May 2015, a good three years after E-waste Rules, 2011, came into effect. Thus, even today there is no system in place to get producers to manage e-waste.

\subsubsection{Manufacturer Responsibility}

There is a report by Toxics Link, which has analysed the performances of 50 top electrical and electronic brands or Producers (as per definition in the Rules) and also at the measures taken by SPCBs to ensure that the Rules were being followed. The findings were disheartening, with 17 out of the 50 brands completely violating the E-waste Rules and another 15 brands taking very little action. Only 7 producers/Brands had put in place good systems to fulfill their responsibility, with another 11 brands taking fair measures. The Pollution Control Boards, that are the implementing authorities, fared even worse, with most PCBs having failed to initiate any steps on this.

\subsubsection{Lack of Awareness Among Users}

Along with the absence of legislations, lack of awareness among the consumers both businesses as well as households is one of the biggest challenges for the formal recyclers. Sixty-two per cent people are not aware about e-waste and only know the term, claims a survey conducted by a group of students from St Xavier's College. Of the 1,000 people surveyed by the students in a span of two months, 90 per cent said that they were not aware of the agencies processing e- waste. 


\subsection{Lengthy Approval System from Regulatory Bodies to Set Up Facility}

The steps to be followed for establishing an E Waste management facility is given below: -

\subsubsection{Obtain the Consent for Establishment (CFE)}

It's an approval document required prior to the establishment of any industry or process to be obtained from the concerned State Pollution Control Board (State Board) vide section 25 of the Water (Prevention and Control of Pollution) Act, 1974.

\subsubsection{Obtain the Consent for Operation (CFO)}

Depending on whether the project requires a EIA report or not, there are two process of applying for the CFO. After submitting all required documents, the facility should be inspected by the SPCB and upon being satisfied, the CFO is issued. The unit is not permitted to operate till the CFO is issued.

\subsubsection{Authorisation for Handling Hazardous Wastes}

All those who handle e-waste are required to seek authorisation by submitting the application form.

\subsubsection{Registration as Recyclers}

All those engaged in recycling of e-waste to go through the cumbersome procedure of registration including those involved in dismantling activity.

\subsection{Recommendations}

\subsubsection{Creation of Awareness}

Local regulatory bodies are framing policies to generate awareness at a local level. For example, the Central Zone bench of National Green Tribunal (NGT) has given a directive to PCB of Madhya Pradesh, Chhattisgarh and Rajasthan, to make it mandatory for manufacturers and dealers to spend $10 \%$ of the advertisement budget on awareness about the EWaste. Similar policies will help to create awareness about e-waste and importance of proper disposal mechanism.

\subsubsection{Integration of Organized \& Unorganized Sector}

There is a need being seen to integrate the activities of the informal sector into the mainstream recycling of e-waste by dovetailing the activities of informal and formal sector.

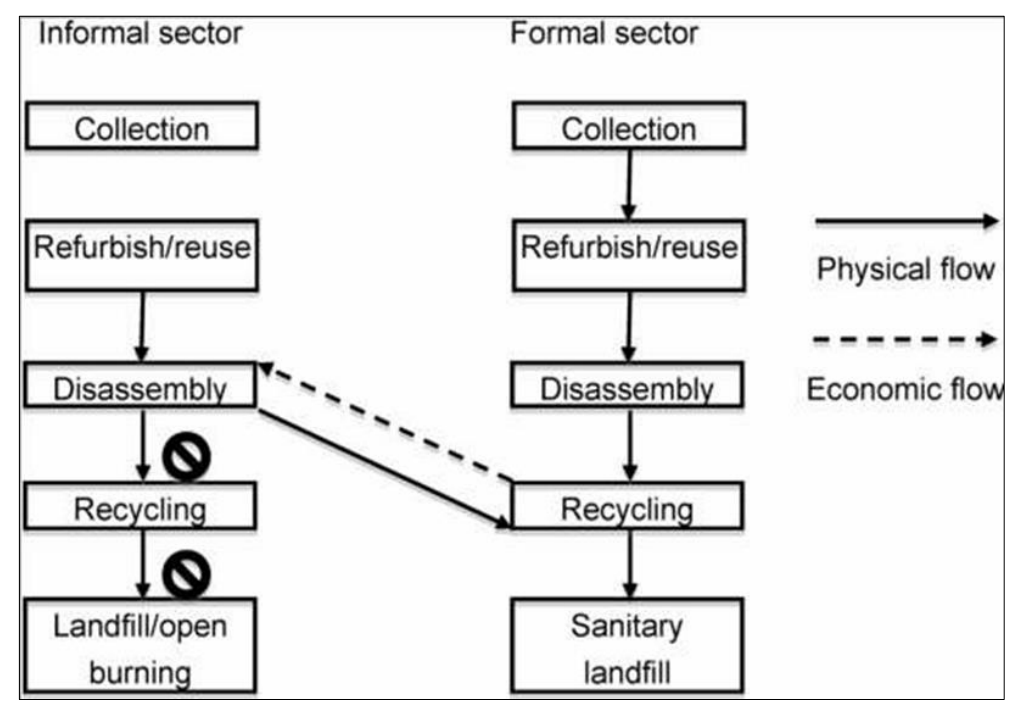

Figure 9 Flow of resources \& funds in E-waste MGT [Source: Dr. Subhash Kumar Verma et. al (2015]

The creation of associations that comprise different informal e-waste recyclers is one possibility towards achieving a formalization of the informal sector stakeholders. These associations would function similar to cooperatives with each having an individual institutional set-up depending on their members. The creation of an association would facilitate 
formal registration and certification as e-waste recycler. Similar projects have already been taken up in 4 major cities. The benefits of both the sectors can be synced to achieve the common goal of better waste handling and business efficiency. The collection network \& expertise of the unorganized sector can be clubbed with the technologically advanced and better infrastructure of the organized sector. Currently the organized sector is sourcing waste through tieups with various corporate consumers like TCS, WIPRO, HP, Infosys etc. apart from the usual bidding process. The procurement happens at the rate of Rs. $1015 / \mathrm{kg}$. The extracted metals and usable parts are sold to manufacturers who use this as raw material. Some part of the margin money can be used to procure e-waste collected from these informal groups or association, thereby giving them volume advantage during batch processing. A pictoral flow of resources $\&$ funds is depicted below.

\subsubsection{Incentive \& Punitive Action}

Lack of motivation for the top management of producers is one of the major concerns and is unable to drive the e-waste management initiative. About $90 \%$ of Indian electronic producing companies and IT companies are not in favor of the EPR concept as it will only increase their cost burden. A two pronged approach, involving both punitive action and incentives, is the need of the hour. Punishment may include fees or fines for dumping electronic devices in the garbage bin. To implement this, stronger regulation is needed with better role clarity, definition of different waste categories, and clarity on penalty clauses on non-compliances. Incentive could involve public and private programs that create incentives to reuse products and also to declare the amount of WEE generated as part of their annual reports and amount disposed using responsible methods.

\subsubsection{Faster Clearance of Projects}

Clearance and licencing of projects on effective e-waste disposal should be expedited so that entrepreneurs are encouraged to set up more \& more enterprises in different parts of the country to address this problem. Tax sops would be a welcome policy from Government to help resolve the high initial investment costs.

\subsubsection{Misc. Recommendations}

There are various other recommendations required to be imple on a day to day basis, which however needs emphasising and publicising:-

- The producers and collection centres should mention their address, telephone number and e-mail clearly on the equipment, which are visible to the consumers clearly.

- Manufacturing the product in such a way that it uses the least amount hazardous materials.

- Using safe non-renewable materials that are safer and can be reused repaired or upgradable is the best way of ensuring in the reduction of e-waste.

- $\quad$ E-wastes should never be disposed with garbage and other household wastes.

- NGOs should adopt a participatory approach in mgt of e-wastes.

- The producer and manufacturer should give a handbook detailed of hazardous effects, handling measure, contact details of manufacturer, refurbisher, dismantler, dealers and guidelines to avoid e-waste to consumers/bulk consumer along with the electrical and electronic equipment.

- The unloading of e-waste/end of life products should be carried out in such a way that there should not be any damage to health, environment and to the product itself. Unloading of CRT, LCD / LED / Plasma TV, refrigerator, air conditioners and fluorescent and other mercury containing lamps should be carried out under supervision in such a way to avoid breakage.

\section{Limitations of the study}

The study is primarily a descriptive study involving qualitative analysis of available literature obtained from the library and web. It does not involve an on-ground or on-site evaluation or assessment, quantitative data assessment or survey component of knowledge, attitude and practices in the environment; which would have enhanced the external validity of the study.

\section{Conclusion}

While formal dismantlers and recyclers are very aware of the health and environmental problems surrounding e-waste, the informal collectors, traders, dismantlers and recyclers working with e-waste are often either unaware of the problems or do not see the necessity to act upon them. The collectors have no reason to change anything, as their business causes harm neither to the environment nor to health. The same applies to the waste traders who often do not 
even see the waste but rather coordinate the waste flow. The problems affect informal dismantlers and recyclers most. As a result, the severity of the environmental and health hazards depends very much on the processes applied. While the workers are often aware of the problems, they are unable to change anything. Due to the illegal nature of their business, they have no possibility to ensure that the e-waste is recycled in an environmentally and health friendly way.

The awareness among manufactures has increased over the last couple of years. Until recently the manufacturing industry was very reluctant to associate itself with the problem and acknowledge its responsibility. A study conducted by Greenpeace India in 2008 assessed which manufacturers had a take-back policy in place and actual take-back systems in operation. Of the 20 monitored brands, nine had no take-back service in place. Several had only one collection centre or limited the take-back to one product (e.g. mobile phones).

Moreover, the majority of the brands had no information on their take-back systems on their websites and none of them had spent a considerable amount of money on raising awareness. There are no guidelines given to consumer or bulk consumer for the handling of electrical and electronic equipment. Also there are lengthy procedures in case of financial penalty pay in case of violation of rules mentioned under E-Waste (Management) Rules, 2016.

The result of the implementation of E-Waste (management) Rules, 2016 has still to come.

\section{Compliance with ethical standards}

\section{Acknowledgments}

Indian Armed Forces.

\section{References}

[1] Text of the Basel Convention on the Control of Transboundary Movements of Hazardous Wastes and Their Disposal, UNEP, Geneva, Switzerland. 6.

[2] Performance Audit on Management of Wastes in India, Report No. PA 14 of. 2008.

[3] J Huisman, Eco-efficiency evaluation of WEEE take-back systems, Waste Electrical and Electronic Equipment (WEEE) Handbook. 2012; 93-119.

[4] The Step Initiative, www.step-initiative.org

[5] Directive 2012/19/EU of the European Union and of the council of date on 4 July 2012 published in issue L197 of the Official Journal on 24 July 2012.

[6] http://www.electronicstakeback.com/home/, The Electronics Takeback Coalition, Scope of Products in E-Waste Laws, view file: last accessed on 21 February 2014.

[7] Discard, Merriam-Webster, www.meriamwebster.com/dictionary/discard: last accessed on 21 February 20146 Discard, Collins, www.collinsdictionary.com/dictionary/english/disca rd: last accessed on 21 February 2014.

[8] Discard, Collins, www.collinsdictionary.com/dictionary/english/disca rd: last accessed on 21 February 2014.

[9] Step Initiative, One Global Understanding of Re-Use - Common Definitions (White Paper), 6, 20098 Step Initiative, One Global Understanding of Re-Use - Common Definitions (White Paper). 2009; 6.

[10] Microelectronics and Computer Technology Corporation (MCC). 1996. Electronics Industry Environmental Roadmap. Austin, TX: MCC.

[11] Lok Sabha Unstarred Question no.650, dt. 28.07.2010.

[12] Sandeep Joshi, 'Growing e-waste is causing concern', The Hindu. 28 February 2009.

[13] National Academy of Sciences, Toxicological Effects of Methyl Mercury. 2005.

[14] PVC: Bad News Comes in Threes, Center for Health and Environmental Justice. December 2004; 23.

[15] Coming Clean, Body Burden Case Studies www.chemicalbodyburden.org.

[16] Greenpeace, Toxic Tech-Chemicals in Electronics. 2005. 
[17] Cormier SA, Lomniki S, et al. Origin and health impacts of emissions of toxic by-products and fine particles from combustion and thermal treatment of hazardous wastes and materials. Environ Health Perspect. 2006; 114: 81017.

[18] Sthiannopkao S, Wong MH. Handling e-waste in developed and developing countries: Initiatives, practices, and consequences. Sci Total Environ. 2012.

[19] WEEE CRT and Monitor Recycling. Executive blueprints.com. 2 August 2009. Retrieved 8 November 2012.

[20] Chen, Aimin; Dietrich, Kim N.; Huo, Xia; Ho, Shuk-mei. Developmental neurotoxicants in e-waste: an emerging health concern. Environmental Health Perspectives. 2011; 119: 431-438.

[21] About the Basel Action Network BAN.org. Accessed: 5 August 2013.

[22] MAIT-GTZ (2007). E-waste Inventorisation in India, MAIT-GTZ study.

[23] Sthiannopkao S, Wong MH. 2012.

[24] Yuan C, Zhang HC, McKenna G, Korzeniewski CLi J. Experimental Studies on Cryogenic Recycling of Printed Circuit Board. International Journal of Advanced Manufacturing Technology. 2007; 34: 657-666.

[25] Chatterjee S, Kumar K. Effective electronic waste management and recycling process involving formal and nonformal sectors. International Journal of Physical Sciences. 2009; 4(13): 893-905.

[26] Manomaivibool P. Extended producer responsibility in a non-OECD context: The management of waste electrical and electronic equipment in India. Resources, Conservation and Recycling. 2009; 53: 136-144.

[27] MoEF. Guidelines for Environmentally Sound Management of E-waste (as approved vide Ministry of Environment and Forests (MoEF) letter No. 23-23/2007-HSMD; 2008. dated March 12, 2008.

[28] The Basel Action Network (BAN) and Silicon Valley Toxics Coalition (SVTC), Exporting Harm. The High-Tech Thrashing of Asia. 25 February 2002; 11.

[29] Schwarzer S, AD Bono et al. E-waste, the hidden side of IT equipments manufacturing and use', Environment Alert Bulletin (UNEP Early Warning on Emerging Environmental Threats). 2005.

[30] GS Mudur. Rest in Pieces, The Telegraph. 28 March 2004.

[31] Radha Venkatesan. Is India a global trash can?, The Times of India. 24 April 2010.

[32] Nations University, IAS - SCYCLE, Bonn, Germany, 2015.

[33] MAIT-GTZ study on Assessment of e-waste in India, Business Standard, India. 2008.

[34] Khattar et al. E Waste Assessment in India: Specific Focus on Delhi; A quantitative understanding of Generation, Disposal \& recycling of Electronic Waste 2007.

[35] What India knows about E-waste. Report on awareness levels of E-waste among common citizens in India. Toxics link Sep 2016.

[36] Das \& Das, Growing Menace of E-Waste in India: Need of Systematic Management, Journal of Chemical, Biological and Physical Sciences. 2015; 2249-1929.

[37] A Jayapradha, Scenario of E-waste in India and application of new recycling approaches for Ewaste management, Journal of Chemical and Pharmaceutical Research. 2015; 7(3): 232-238.

[38] Are we ready to do-it-ourselves? Exploring diy opportunities in india. Tejas Home 2016.

[39] Time to Reboot II, - Report by Toxic Link. 2015.

[40] http://timesofindia.indiatimes.com/city/bengaluru/Singapore-Japan-get-rich-on Bangalores-ewaste/articleshow/22643100.cms.

[41] Creating green jobs through safer and cleaner e-waste recycling practice in India - A report by Switch Asia. 2014.

[42] Dr. Lakshmi Raghupathy et al. E-Waste Recycling in India - Bridging the Gap between the Informal \& Formal Sector, MAIT-GTZ. 2010.

[43] A Jayapradha. Scenario of E-waste in India and application of new recycling approaches for Ewaste management, Journal of Chemical and Pharmaceutical Research. 2015; 7(3): 232-238. 
[44] E-Waste in India - Implications, Issues \& recommendations for Handling Home Appliances and consumer electronics Paper by APCO.

[45] E-Waste In India. Research Unit (Larrdis) Rajya Sabha Secretariat New Delhi. June 2011.

[46] S Sinha, P Mahesh, E Donders, WV Breusegem. Waste Electrical And Electronic Equipment. The EU and India: sharing best practices. www.toxicslink.org

[47] E-Waste: The Exploding Global Electronic Waste Crisis. An issue briefing book. Electronics Take Back Coalition.

[48] The Gazette of India, Extraordinary Part-II, Section- 3, Sub-Section (i) Government Of India, Ministry Of Environment, Forest And Climate Change. Notification. 23 March 2016. 